\title{
В.Н. Филас
}

\section{СЕВЕРНОЕ ПРИЧЕРНОМОРЬЕ НА КАРТУШАХ ГЕОГРАФИЧЕСКИХ КАРТ ХVI — НАЧАЛА ХVIII ВВ.: ОСОБЕННОСТИ ЕВРОПЕЙСКОГО ВОСПРИЯТИЯ*}

Формирование представления о Северном Причерноморье происходило не только путем научного познания, но и другими путями - в первую очередь художественным. С накоплением знаний о Северном Причерноморье сформировался определенный образ, бытовавший в европейском обществе. Этот образ транслировался в различных формах, одной из которых стали картуши на географических картах, которые сейчас можно считать одним из важных источников, обладающим высоким информационным потенциалом, способным раскрыть основные черты региона и представления о нем на протяжении XVI-XVIII вв.

Структурный анализ картушей дает возможность говорить как о реальной информации, отображающей историческую действительность, так и об устоявшихся стереотипах и информации программного характера. Сюжеты картушей в основном апеллировали к историческому прошлому, воплощали социальную пропаганду европейских ценностей, поляризовали образы цивилизационного Запада варварскому Востоку, указывали на особенности противостояния в северо-причерноморских степях.

Ключевые слова: карта, картуш, образ, представление, противостояние, Северное Причерноморье, сюжет.

Сведения об авторе: Филас Виктор Николаевич, доктор исторических наук, доцент, Хортицкая национальная академия.

Контактная информация: 69017, Украина, г. Запорожье, ул. Наукового городка 59, Хортицкая национальная академия; e-mail: filasvn@gmail.com.

\section{Viktor Filas}

\section{NORTHERN BLACK SEA REGION ON CARTOUCHES OF GEOGRAPHICAL MAPS OF THE $16^{\text {th }}-$ EARLY $18^{\text {th }}$ cc.: FEATURES OF EUROPEAN PERCEPTION}

The formation of the understanding of the Northern Black Sea region took place not only through scientific knowledge, but also in other ways - primarily artistic. With the accumulation of knowledge about the Northern Black Sea region, a certain image was formed in European society. This image was transformed in various forms, one of which became cartouches on geographical maps, which can now be considered as one of the important sources with high information potential, capable of revealing the main features of the region and ideas about it during the $16^{\text {th }}-18^{\text {th }}$ centuries.

Structural analysis of cartouches makes it possible to talk about both real information that reflects historical reality, and about established stereotypes and information of a program nature. The plots of the cartouches mainly appealed to the historical past, embodied the social propaganda of European values, polarized the images of the civilizational West to the barbaric East, pointed to the peculiarities of the confrontation in the Northern Black Sea steppes.

Key words: map, cartouche, image, representation, opposition, Northern Black Sea region, plot.

\footnotetext{
* Статья написана при поддержке Canadian Institute of Ukrainian Studies (Edmonton, Canada). 
About the author: Filas Viktor, Doctor of Historical Sciences, Associate Professor, Khortytsya National Academy.

Contact Information: 69017, Ukraine, Zaporizhzhia, 59 Naukove Mistechko Str., Khortytsia National Academy; e-mail: filasvn@gmail.com.

Начиная с эпохи Возрождения, составной частью многих географических карт становится еще один элемент - художественный картуш, обрамляющий легенду карты, а история картографии получает ещё один «текст» для исследований. Говоря о картуше в картографии, следует понимать, что, перейдя из формы архитектурного декора эпохи барокко и рококо в картографию, картуш сохранил одно из своих предназначений создание плоскости для текста, сохранив свой изначальный декоративный смысл. Впоследствии, картуш «разросся» до понимания многослойной художественноинформационной составляющей карты.

Структурно картуши карт Северного Причерноморья XVI - начала XVIII вв. состоят из трех частей: базовой, орнаментальной и предметно-художественной. Каждая из этих частей несет определенную функцию и информацию. Базовая часть в художественном выражении представляет собой условный щит, овал, круг, кусок ткани, деревянную тумбу, камень или собственно картуш как архитектурную форму, на которой размещается текст, содержащий название карты, масштаб, имя её автора и гравера, а также место и год издания. Иногда текст базовой части содержит и посвящение. Базовая часть часто имела орнаментальное оформление в виде растительного, иногда животного или простого геометрического декора. Орнаментальная часть выполняет эстетические функции и несет информацию о стиле, периоде, вкусах и особенностях декора представленной эпохи. Последняя часть картушей карт представляет собой предметно-художественную композицию, которая, в свою очередь, может быть двух видов: простой - предметно-образной, или сложной - сюжетной. Предметно-образные картуши обычно содержат изображение одного или нескольких предметов или образов, символически относящихся к данной территории или реже к картографии. Они отображают известные особенности территории, представляя её предметно-образные маркеры. Сюжетные картуши, по выражению Н. Финягиной, представляют собой художественные элементы, объединенные общим замыслом в единую композицию, и помогают воспринимать карту (Финягина 2006: 10-11). Сюжетная композиция включает в себя программно-информационные компоненты, а также может иметь предметно-образные маркеры, связанные одним замыслом и несущие аллегорические, иносказательные и другие смыслы. Художественные композиции выполняют эстетическопрограммные функции и как любые иконические символы способны нести в себе визуальную оценочную информацию.

Период с XVI по XVIII в. был временем, когда декоративные картуши не только заполняли пространство карт, но и были неотъемлемой их частью (Barberand, Boardin 1993: 76). Важнейшей составляющей этих картушей, кроме практических данных и эстетической нагрузки, была и визуальная информация о картографируемой территории, зашифрованной в различные образы, аллегории, иносказания и т.д. Считается, что первыми картуш на карту добавили итальянские картографы XVIв. Эту традицию продолжили французские и немецкие картографы (Lynamin 1953: 48). На начальных этапах художественного оформления карт в подавляющем большинстве случаев картуш имел лентообразную форму, куда было вписано её название. Художественное оформление карт, в том числе и картушей, в общем контексте художественных стилей и эстетики позднего Возрождения и барокко 
перекочевало из Италии в Голландию. Голландцы стали лидерами в области картографических изданий, которые первоначально копировали карты своих итальянских предшественников. Шаблоны для картушей голландские мастера нашли в искусстве итальянского Возрождения, в первую очередь, в скульптуре, резьбе по дереву, архитектурном декоре и декоративной штукатурке. Впоследствии голландские мастера стремились «оживить» и «осмыслить» эти «шаблоны», иллюстрируя картуши предметами, животными и фигурами, относящихся к территории, изображенной на карте. Именно голландская художественно-оформительская традиция превратила картуш в художественное произведение и визуальное информационное сообщение, которым он оставался в картографии вплоть до средины XIX в.

Трансформации картуша в XVI-XVIII вв. предшествовала бурная «капиталистическая» трансформация голландской экономики и превращение этой страны в ведущую морскую торговую державу. Такое превращение закономерно тесно связано с развитием картографии. Интенсивность голландского мореплавания постепенно расширяла географические знания о мире и приводила к нанесению и уточнению этих знаний на карте. Голландские мастера все чаще предпочитали более затратную резьбу по металлу более простой в технологическом исполнении ксилографии. Гравюра на металле позволяла давать тоньше линию и создавать другие эффекты, недоступные ксилографии. Эти особенности техники гравюры на металле давали возможность, во-первых, точнее и детальнее отображать на карте картографируемые объекты, а во-вторых, - вместить гораздо больше визуальной информации. Кроме этого гравюра дает в десятки раз больше оттисков, чем ксилография. Это сделало гравюру в условиях «коммерциализации» картографии в Голландии доминирующей и удобной техникой тиражирования карт. Карта в Голландии XVII в. стала товаром, ориентированным на массового потребителя.

На «товаризацию» и «коммерциализацию» картографии естественно оказал влияние и стремительный расцвет живописи и графики, известный как «Золотой век голландской живописи», представленный именами таких мастеров, как Рембрандт, Франс Халс, Ян Вермеер, Питер де Хох, Ян Стен, Герард Терборх, Якоб ван Рёйсдал и других. Их работы оказали принципиальное влияние на последующие эпохи развития изобразительного искусства во всем мире. Географическая карта в Голландии становится большим, нежели просто графически исполненная обобщенная модель географических пространственных знаний. Карта приобретает значение не только с практической точки зрения, но и обретает свою новую сущность как предмета эстетики интерьера. Карта в голландский золотой век становится объектом живописи. Достаточно взглянуть на работы Яна Вермеера, творчество которого принято считать вершиной искусства золотого века Голландии. В работах «Молодая женщина с кувшином воды», «Женщина с лютней», «Женщина, читающая письмо», «Аллегория Живописи», «Офицер и смеющаяся девушка» и других бытовых полотнах мастера карта является доминантой заднего плана в интерьерах. Кроме того, изображенные карты являются не вымышленными, а реальными, изданными в основном известной издательской мануфактурой Блау, ведущей в тот момент в Голландии. Карта становится объектом живописи, с одной стороны, и, с другой стороны, живопись приходит на карту в виде различного рода изображений на плоскости карты, а также оформления картушей.

Одним из результатов этого взаимопроникновения стало появление визуального текста карт, несущего порой неожиданную информацию о картографируемой территории. Этот визуальный срез состоит как из реальной информации, отображающей историческую действительность, так и из устоявшихся стереотипов и информации программного 
характера, что отображает представление, или формирует мнение о территории. Это делает картуши, особенно их предметно-художественную часть, очень важным источником в исследованиях, посвященных формированию образов и представлений о регионе, а также визуальным идеологическим «освоениям» территорий. Особенно данный тезис актуален на фоне того, что в историко-картографических исследованиях картуши на картах воспринимались лишь как эстетическое сопровождение, повышающее привлекательность карты. И этому есть свое объяснение. Чтобы прочитать визуальный текст картушей недостаточно только картографических знаний. Без специальных знаний семиотики, искусствоведения, истории картографируемого региона невозможно получить какую-либо информацию, полезную для историка. Поэтому, естественно, к картушам не присматривались и не стремились «замечать» в нем источник.

Картуши зачастую несут символический смысл и информацию о картографируемой территории. В картушах в основном звучат темы экономики, однако присутствуют и исторические, религиозные и политические тематические направления. Это отмечали многие исследователи картографии в своих работах. Впервые на картуш как исторический источник по истории Северного Причерноморья обратила внимание Н. Финягина. Она на примере исследования Российского атласа 1792 г. показала, как сюжетные картуши раскрывают значение различных административных единиц, в том числе Екатеринославского наместничества и Таврической области, в экономической и культурной жизни Российской империи в её историческом прошлом (Финягина 2006: 43, 45).

Тематическое содержание предметно-художественной части картушей карт Северного Причерноморья на протяжении XVI-XVIII вв. изменялось в соответствии с событиями и фактами в жизни региона, а также в связи с трансформацией европейских политических, социально-экономических и культурных парадигм. Тематически сюжеты в основном апеллировали к историческому прошлому, воплощали социальную пропаганду европейских ценностей, поляризовали образы цивилизационного Запада варварскому Востоку, указывали на особенности цивилизационного противостояния в северо-причерноморских степях. Северное Причерноморье в публикации понимается как историко-географический регион, являющийся западным краем большого пояса евразийских степей. Такое понимание региона достаточно популярное в археологических исследованиях, а также в исследованиях древней и средневековой истории.

Самая ранняя тематика северо-причерноморских картушей апеллирует к историческому прошлому Тавриды или античному «civilis». Картуш, который содержал «смысловое» значение, впервые появился на карте северо-причерноморского региона, изданной в Амстердаме в 1595 г. известным картографом Герардом Меркатором (1512-1594). Данная карта содержала картуш в виде овального щита, который сверху и снизу украшен стилизованной парой рогов быка (Mercator 1595). Это животное еще с античных времен связывают с Таврикой и племенами тавров. Действительно, Диониса Загрея изображали с рогами. Из-за этой символической связи возникло убеждение, что он первым запряг быков в плуг. Учтем, что эллины дали название таврам с учетом того, что они почитали быков. Это дает нам право утверждать, что «легендарная» пара быков и основной их визуальный маркер - два рога, в европейской средневековой традиции соотносились с Таврикой и с Северным Причерноморьем. Собственно говоря, этот графический символический посыл есть не что иное, как наследие эпохи Возрождения с её ориентацией на античные заимствования и как следствие «возрождения» античной памяти, выразившейся в виде символа быка на картуше, который визуально олицетворяет регион. 
В 1644 г. карта Г. Меркатора была переиздана в Амстердаме, но уже другим издателем - Яном Янсониусом (1588-1684) и с новым сюжетным картушем. Этот картуш представляет собой изображение мужчины с цепом в руке и собаки справа, а слева женщины, прижимающей к себе сноп пшеницы. Над картушем «нависают» слева двое детей с колосьями все той же пшеницы, а справа два тучных быка (Janssonius 1644). Собственно говоря, сюжет картуша иконографически вообще никакого отношения к Северному Причерноморью не имеет. В одежде мужчины и женщины явно прослеживаются особенности кроя, присущего крестьянской одежде Голландии или Фландрии. Сюжет этого картуша представляет собой аллегорию достатка и семейного благополучия, взятый из визуальной традиции Голландии.

В сюжете этого картуша воплотилась социальная пропаганда ценностей, таких как благополучие, богатство и труд. Сюжет картуша Я.Янсониуса привлекает внимание к существованию этих ценностей в Голландии. Разместив их на карте в виде художественного оформления картуша, издатель как бы поляризует эти положительные символы протестантской этики с уже известным «варварским» образом северо-причерноморского региона. Это вполне укладывается в веберовское объяснение роли протестантской этики, выдвинутое позже уже в XIX в., которая была обусловлена трудовым рвением и рациональной организацией труда, создавала благополучие и богатство европейской и американской экономик (Вебер 2017). Популярность этой карты говорит о том, что она спустя почти сорок лет с таким же картушем была переиздана в 1680 г. в Лондоне известным картографом и гравером Питером Шенком (Schenk 1680).

Карту Северного Причерноморья Г. Меркатора в 1645 и 1657 гг. переиздавал также известный голландский издатель, картограф и гравер Ян Блау (1596-1673). Картуши этих карт были художественно «скромнее» предыдущих. Они выполнены в лучших традициях барокко и представляли собой завитые листы бирюзового и золотистого цветов, внутри которых на распластанной обработанной шкуре красовалось название карты (Blaeu 1645). Такой элемент декора картуша как шкура всегда семиотически апеллировал к «дикости» и «отсталости», что мы увидим и в других картушах применительно к Северному Причерноморью. Именно этим маркером Я. Блау и обозначил одно из европейских восприятий северо-причерноморских территорий, изображая шкуру как элемент картуша. Распластанная обработанная шкура толкает нас в понимание того, что она принадлежала некогда быкам Диониса, который принес в Тавриду античный «цивилизационный» уклад, но пришлые «варвары» (скифы, татары) этот уклад не восприняли и уничтожили. Здесь на лицо конфликт земледельческого (античного, европейского) и кочевого (скифского, татарского) хозяйственного уклада. Для первых бык это, в первую очередь, тягловая сила и средство производства, а для вторых — это пища (мясо) и сопутствующие материалы (шкура). Идеологический барьер взаимопонимания между европейским миром и северопричерноморским регионом имел не только политическое или религиозно-культурное происхождение. Он укреплялся и разным пониманием значения тех или иных средств производства в условиях разных хозяйственно-культурных типов (рис. 1).

Начиная с 1595 г., времени появления первой карты Северного Причерноморья с картушем Г. Меркатора, имеющим «смысловое» значение, и вплоть до средины XVII в. наполнение визуальных текстов картушей формировалось на основе двух тематических композиций. Во-первых, визуальные тексты картушей рефлексируют по прошлому региона, где некогда существовал «прогрессивный», античный «civilis», ставший основой европейской цивилизации. Во-вторых, в сюжетах картушей присутствует тема демонстрации западноевропейского экономического успеха. 
C середины XVII в. тематика картушей становится разнообразней за счет появления новых тематических решений, которые восходят к бытующим в то время в Европе историкоидеологическим установкам и ментально-географическим представлениям. Эти новые тематические направления, исходя из особенностей построения композиций и наполнения картушей, можно условно назвать - поляризацией и противостоянием. Поляризация, композиционно представленная по вертикали, противопоставляет образы цивилизационного Запада варварскому Востоку, тем самым указывая на доминирование (расположенного в картуше выше) европейского культурного и экономического уклада над восточным. Подобная вертикальная ориентация сюжета восходит еще к древнеегипетскому искусству, когда мир мертвых изображался внизу, а живых сверху. Этот прием, но уже с новыми образами, использовался в христианской иконописной традиции, получивший широкое распространение и в эпоху Возрождения, и последующие периоды. Ориентируя сюжет сверху вниз художники поляризовали добро и зло, светлое и темное, жизнь и смерть, рай и ад, тем самым несли идею триумфа положительного над отрицательным. Противостояние же, в отличие от поляризации, имеет горизонтальную композиционную ориентацию и формирует представление об остроте и особенностях цивилизационных противоречий в степях Северного Причерноморья.

Поляризация присутствует на картуше к карте французского историка и картографа Николя Сансона (1600-1667) «Tartarie Europeenne ou Petite Tartarie», вышедшей в 1665 г. Следует отметить, что территория Крымского ханства цивилизационно для европейцев была составной частью субрегиона «Великая Тартария» и входила в её состав под названием «Малая Тартария» («Petite Tartaria», «Piccola Tartaria»). Картуш карты не имеет сюжетного сопровождения, однако его орнаментальная часть подчеркивает цивилизационную «полярность» жителей Европы и Тартарии. Базовая часть картуша представляет собой мантию, в которую вписано название карты, дата и место издания. Базовую часть обрамляет растительный орнамент и фигурки путти (художественный образ маленького мальчика или мальчика-ангела, популярный в искусстве Возрождения, барокко и рококо) (Sanson 1665). При общем впечатлении композиционного единства в картуше при анализе семиотики деталей орнамента наблюдается четкое идеологическое и цивилизационное разделение на верхнюю и нижнюю части. Верхняя часть картуша увенчана лавровым венком - символом триумфа и победы. Этот же символ триумфа и победы обрамляет картуш слева и справа — в виде пальмовых венков, окутанных красной триумфальной лентой. Сверху мантию с данными о карте придерживают два парящих ангела-путти. В нижней же части эту мантию поддерживают тоже два пути, восседающие на меандровых листьях. Однако нижние путти представляют собой изображение людей, только по пояс, ниже они уже переходят в зверей с шерстью и копытами. Этим подчеркивалось наличие в них «нечеловеческих» черт. Верхняя часть картуша олицетворяет «civilis», а нижняя — «barbarus» (рис. 2).

Подобное поляризационное тематическое композиционное решение применено и в карте «Tabula geographica qua pars Russiae Magnae pontus Euxinus seu Mare Nigrum» авторства Иоганна Баптиста Хаманна (1663-1724), вышедшей предположительно в 1720 г. в Нюрнберге. Базовая часть картуша с названием и данными о карте представляет собой мантию, увенчанную российским гербом. Эту мантию поддерживают, паря в небе, три ангела. Левый облачен в шлем Минервы - богини мудрости и войны, а центральный держит меч - символ победы и ратной славы. У путти слева присутствует развевающийся на ветру элемент античной драпировки в одежде. Под базовой частью внизу изображена восседающая на облаках полуголая мужская фигура, прикрытая шкурой животного, сидящая напротив зеркала. При этом сама фигура отображается в зеркале в виде черного кота (Нomann 1720). 
Композиционный замысел сюжета картуша сводится к тому, чтобы на контрасте продемонстрировать циничность и двуличие «варваров», которым не следует доверять (рис. 3).

Дело в том, что европейцы еще с античного «civilis» четко противопоставляли себя северо-причерноморскому «barbarus» и считали их опасными и контрпродуктивными. Впоследствии в средние века и новое время на цивилизационный критерий наслоился и религиозный с его христианской этикой как основой экономического прогресса. Теперь «civilis», который ассоциировался с «christianitas» (христианство), противопоставлял себя «barbarus», за которым закрепилось «religia pagana» (язычество) или «inf deles» (неверные) (Filas 2018: 13). Татары и скифы, как в средние века, так и новое время считались в Европе народами тождественными. Об этом писали многие авторы. Так, Л. Вульф приводит цитату британского капитана Дж. Смита, который находился в татарском плену в 1603 г. и под впечатлениями отметил, что: «...Татария и Скифия - одно и то же...» и «... эти (татары) крайне варварский народ» (Вульф 2003: 44). Известный британский историк и мемуарист Э. Гиббон, который никогда не был в Северном Причерноморье, смело отождествлял татар со скифам, считая их естественно варварами, «приближенных к звериному состоянию» (Gibbon 1906: 341). «Нет нужды повторять несложное и всем известное описание татарской морали» - особо не углубляясь в подробности, давал оценку человеческим качествам татар Э. Гиббон (Gibbon 1906: 180). Естественно, что мнение Э. Гиббона опиралось на устоявшие стереотипные знания в Европе о нравах жителей региона, сформированных в более ранние эпохи. Ранние средневековые источники фиксируют продолжение «античного формата» восприятия образа Северного Причерноморья. Они часто давали племенам, обитавшим в регионе в IV-X вв. такие характеристики, как «отвратительные и худшие из рода людей» (Загадки 1995: 417), «жестокие злодеи, которые едят человеческое мясо» (Бременский А. 1989: 138), «свирепые, звероподобные, которые едят сырое мясо и пьют человеческую кровь» (Оттон Фрайзингенский 2010: 238-239), «худшие и самые жестокие из всех язычников, обитающих на земле» (Кверфуртский 2010: 57-58). Подобные эпитеты говорят о том, что средневековые авторы неоднократно акцентировали внимание на враждебности и деструктивности северо-причерноморского населения для европейского мира.

Нарративы средневековых авторов нашли свое продолжение и в новое время, отобразившиеся в визуальных текстах, где в образах скифов, которых считали предками татар, присутствуют элементы антично-средневекового мифологически-религиозного представления европейцев о регионе к востоку от христианской Европы. Ксилография Авраама де Брейна, изображающая скифского всадника, изданная в 1581 г,, является характерным примером стереотипного «варварского» восприятия этого народа. Источником для работы А. Брейну служили устные представления, легенды и воображения о некогда кочующем степями Северного Причерноморья народе, которые он «перевел» в визуальный текст ксилографии. Не имея представления об одежде скифов, А. Брейн «одел» воина в одежду европейского покроя. Однако материалом одежды всадника были не произведенные ткани как маркер экономического прогресса, а обычная сильно ворсистая и плохо обработанная шкура животных как свидетельство хозяйственной отсталости. Тем самым автор подчеркнул экономическое и культурное положение скифов по отношению к цивилизованным мирам. Суровый и злобный нрав скифов подчеркнут изображением колчана для стрел, сделанным из человеческой руки и наличием трех отрубленных голов, привязанных к седлу. В руке скифский воин держит двухсторонний топор - сагарис, который был распространён у скифов (Hrd., VII, 64). На острие топора насажена человеческая голова, в которой узнаются «греческие» черты (борода, курчавые волосы, овал 
лица). Голова скифа и его жертвы находятся на одном уровне. При этом скиф вглядывается в лицо «грека». Этим Брейн пытался визуально выразить противостояние «античного» и «варварского», а также показать пагубность существования варваров для развития «цивилизованных» народов и подчеркнуть их непонимание и недооценивание культурноэкономических достижений Европы (рис. 4).

Рефлексия к исторически-родственному цивилизационному прошлому и демонстрация современного экономического успеха на картушах карт отображали идеологию европейского цивилизационного христианского единства, которое поляризовало себя к «отсталому» и «варварскому» Востоку. Условная линия разграничения «своего» европейского и «чужого» варварского проходила по степям Северного Причерноморья. Это цивилизационное противостояние на фронтирах в степях, а также стереотипные представление о народах Северного Причерноморья с особой силой отобразилось на картушах карт, начиная со средины XVII в. События Освободительной войны Богдана Хмельницкого (1648-1654 гг.) сделали определенный резонанс в Европе. Они привлекли внимание и вызвали интерес в европейском обществе к Северному Причерноморью как сопредельному региону с Гетманщиной и Речью Посполитой, где в основном и происходили события восстания. Одной из реакций, направленной на удовлетворение интереса в Европе к региону, стало издание в 1650 г. первой подробной карты гетманской Украины и смежных с нею земель, в том числе и Северного Причерноморья. Карту от руки составил французский военный инженер и картограф Гийом де Боплан (1595-1673) еще в 1638 г., а через десять лет её гравировал и издал Вильгельм Гондиус (1598-1652/58) в Данциге.

На картуше слева от надписи названия карты и герба Речи Посполитой изображен вооруженный казак, позади которого стоят украинские крестьянин и крестьянка. Слева изображен сидящий татарин с руками за спиной, а рядом женщина со скорбным лицом. Сущность этого европейского визуального посыла можно трактовать как положительный образ казака «защитника» украинского народа от татар, которых он победил. Об этом говорит обратное изображение обезоруженного татарина в профиль с опущенной головой и руками назад. Рядом сидит опечаленная женщина (Hondius 1648).

Более динамично представлена сцена цивилизационного противостояния в Северном Причерноморье на картуше голландской карты «Tractus Borysthenis», изданной в 1662 г. известным издателем Я. Блау (Blaeu 1662: 4). Четвертый лист карты отображает участок Днепра от современных Черкасс до его впадения в Черное море - регионе повышенной напряженности, противостояния «исламского» и «христианского». Картуш этой части с двух сторон уравновешен вооруженными людьми. В центре композиции изображена плоскость с названием карты, орнаментированной в стиле барокко. По краям этот орнаментированный картуш одной рукой держат справа казак, а слева татарин. В другой руке у казака кирка, а у татарина булава. Рядом возле этих фигур синхронно расположены стреляющие лучники, на заднем фоне обеих композиций изображены наступающие войска. Наличие кирки у казака символа труда и освоения, и булавы у татарина, символизирующую власть, аллегорично отсылает нас к пониманию того, что татары владеют землями в Нижнем Поднепровье, а казаки пытаются их осваивать. И все это происходит на фоне постоянных военных конфликтов, о чем свидетельствует динамика и структура сюжета.

К карте «Tractus Borysthenis» приложены и картуши с масштабом и условными знаками, между которыми изображены домашние животные, которые являлись основой хозяйства населения Нижнего Поднепровья (видимо в порядке важности - лошади - на переднем плане, далее на заднем - крупный рогатый скот, овцы и козы). 
Очень динамичное и в чём-то даже драматичное представляет собой сюжетное обрамление картуша карты Джованни Джакомо Росси (1627-1691), изданной в Риме в 1684 г. (Rossi 1684). Здесь изображено смертельное противостояние казаков и татар с характерным для барокко переплетением тел, подчеркивающих драматургию и усиливающих динамику восприятия происходящего. Сюжетным картушем, где раскрыта тема фронтирного противостояния в Северном Причерноморье, оформлена и карта «Великой Тартарии» известного французского картографа Гийома Делиля (1675-1726), изданная в 1706 г. в Париже. На карте хоть и представлены земли субрегиона «Великая Тартария» (Поволжье, Урал, Сибирь, Дальний Восток, Средняя Азия, Кавказ и Северное Причерноморье), однако сюжет картуша образно связан только с Северным Причерноморьем. Сюжет картуша статичен и имеет четыре основных элемента. Слева изображена конная фигура казака в «гетманской» шапке, который тащит плененного татарина. Снизу — казак, седлающий лошадь для похода (вероятней всего против татар). Справа в полушаге - идущий лучник с явными признаками «европейской» одежды. Над плоскостью с названием карты изображена юрта - традиционное жилище кочевых народов (Del'Isle 1706). Этот сюжет также отсылает нас еще к боплановской аллегории казака христианина и защитника мирных земледельцев от набегов кочевников - не христиан.

Как видим, картушная изобразительная традиция положительно изображает казачество, в отличие от татар, видя в них союзников в борьбе с опасным врагом в большей степени благодаря тому, что казаки были христианами и часто выступали на стороне европейских армий. Многие европейские авторы пишут о казаках как о защитниках христианской веры и отважных воинах, которые противостоят угрозе с Востока. Так, военный деятель Речи Посполитой, итальянец по происхождению Александро Гваньини, проявляет в отношении к населению Северного Причерноморья градацию по религиозному принципу. Запорожских казаков он воспринимает положительно. «Хорошо, что казаки есть», пишет А. Гваньини, намекая на их роль в сдерживании татарских набегов. Зато татары вызывают у него недоверие: «... язычникам (татарам) не можно верить, потому что мы их хорошо знаем по их делам» (Гваньїні 2007: 428). Подобную позицию высказывает и Г. Боплан, когда он говорит о татарах, как о «других», отличных от христиан, которые рождаются как звери с закрытыми глазами и с присущей им природной жестокостью и дикарством в отношении к христианским народам, а казаков, наоборот, идеализирует и хвалит за природный военный талант (Боплан 1832: 41, 52).

Таким образом, рефлексия к античному прошлому, демонстрация благополучия системы, поляризация себя к отсталому и дикому Востоку, а также острота цивилизационного противостояния стали темами, которые сопровождали сюжеты картушей карт Северного Причерноморья и отображали образ региона для европейского христианского мира XVI - начала XVIII в. Этот образ служил как для укрепления внутриевропейских «единств», так и был клапаном для снятия возникающих напряжений. Эти две способности идеологии - укреплять социальные группы и «выпускать социальный пар», К. Гирц в свей теории напряжений назвал соответственно солидаристской и катартической (Гирц 2004: 235-236). Образ Северного Причерноморья как региона с его сформированным в античность и средневековье набором популярных символов, стереотипов и страхов, которые эмоционально напоминали христианскому миру о постоянно грядущей опасности, в значительной степени цементировало как общеевропейскую идеологическую ориентацию на солидарность, так и «отводила» социальные напряжения. 


\section{Литература}

Боплан Г. 1832. Описание Украины. Санкт-Петербург: Типография К. Крайя.

Бременский А. 1989. Деяния Гамбургских Архиепископов. В: Свердлов М.Б. (сост.). Латиноязычные источники по истории Древней Руси: Средина XII - средина XIII в. Москва; Ленинград: Институт истории АН СССР, 138.

Вебер М. 2017. Избранное. Протестантская этика и дух капитализма. Москва; Санкт-Петербург: Центр гуманитарных инициатив.

Вишленкова Е.А. 2011. Визуальное народоведение империи, или «Увидеть русского дано не каждому». Москва: Новое литературное обозрение.

Вульф Л. 2003. Изобретая Восточную Европу: Карта циивилизаџии в сознании эпохи Просвещения. Москва: Новое литературное обозрение.

Гваньїні О. 2007. Хроніка європейської Сарматії. Київ: Києво-Могилянська академія.

Гирц К. 2004. Интерпретация культур. Москва: РОССПЭН.

Загадки 1995: Загадки послания сестре и переписка Бонифация. 1995. В: Иванов С.А., Литаврин Г.Г., Ронин В.К. (сост.). Свод древнейших письменных известий о славянах. Т. 2. Москва: Восточная литература, 417.

Кверфуртский Б. 2010. Послание к Германскому кролю Генриху II. В: Джаксон Т.Н., Коноваловой И.Г., Подосинова А.В. (ред.). Древняя Русь в свете зарубежных источников. Т. 4. Москва: Русский фонд содействия образованию и науке, $57-58$.

Оттон Фрайзингенский. 2010. Хроника (История о двух градах). В: Джаксон Т.Н., Коноваловой И.Г., Подосинова А.В. (ред.). Древняя Русь в свете зарубежных источников. Т. 4. Москва: Русский фонд содействия образованию и науке, 238-239.

Blaeu J. 1645. Taurica Chersonesus, Hodie Przecopsca, at Gazara dicitur. Amsterdam: Edited by Willem and Joan Blaeu.

Blaeu J. 1662. Tractvs Borysthenis Vulgo Dniepr et Niepr dicti, a Chortika Ostro ad Urbem Oczakow. Atlas Maior. Vol. II. Amsterdam: Edited by Willem and Joan Blaeu.

Bruin A. 1581. Ein reuter aus den land Schithia. Imperii ac Sacerdotii Ornatus. Diuersarum item gētium peculiaris vestitus. Coloniae: [s.n.].

Del'Isle G. 1706. Carte de Tartarie. Dressee sur les relations de plusieurs voyageurs de differentes nations et sur quelques observations qui ont ete faites dans ce pais la par Guillaume Del'Isle de l'Academie Royale des Sciences. Paris: Chez l'Auteur sur le Quai de l'Horloge a l'Aigle d'Or avec privilege.

Filas V. 2018. Tradition of European Perception of the Northern Black Sea Region and Its Population at the Time of Antiquity and the Middle Ages. Східноєвропейський історичний вісник 8, 8-17.

Gibbon E. 1906. The Decline and Fall of the Roman Empire. New York: Fred de Fau and Co.

Homann I.B. 1720. Tabula geographica qua pars Russiae Magnae, Pontus Euxinus seu Mare Nigrum et Tartaria Minor: cum finitimis Bulgariae, Romaniae et Natoliae Provinciis exhibe[n]tur. Noribergae: Homann (Schul-Atlas von zwantzig General- und Special-Landkarten).

Hondius G. 1648. Delineatio generalis Camporum Desertorum vulgo Ukraina : cum adjacentibus provinciis / bono publico erecta per Guilhelmum le Vasseur de Beauplan. Danzig: Willem Hondius.

Janssonius J. 1644. Taurica Chersonesus, Hodie Przecopsca, at Gazara dicitur. Amsterdam: Excudebant Janssonio-Waesbergii et Moses Pitt.

Mercator G. 1595. Taurica Chersonesus, Nostra aetate. Przecopsca, et Gazara dicitur. Amsterdam: Gerard Mercator.

Rossi G.G. 1684. Tartaria D Europa ouero Piccola Tartaria divisa da Giacomo Cantelli da Vignola ne Tartari Nogai e del Crim, o di Precop Soggetti al proprio Kam ne Tartari di Budziack, d Oczackow, e di Dobruss, Soggetti al Turco. ne Tartari Circassi, e di Mordua soggetti al Gran Duca di Moscovia e nelle Due Uckraine una abitata da Cosacchi Tanaiti Soggetti al Moscovita, l altra da Cosacchi di Zaporowa, ora liberi, e già dipendenti dalla Polania. Roma: Domenico de Rossi.

Sanson N. 1665. Tartarie Europeenne ou Petite Tartari ou sont Les Tartares, Du Crim, ou de Perecop; De Nogais, D’Oczacow, et de Budziak. Paris: Mariette P.

Schenk P. 1680. Taurica Chersonesus, Hodie Przecopsca, at Gazara dicitur. London: Janssonius-Waesberg / Pitt. 


\section{References}

Boplan, G. 1832. Opisaniye Ukrainy (Description of Ukraine). Saint Petersburg: Tipografiya K. Kraya (in Russian).

Bremenskiy, A. 1989. In: Sverdlov, M.B. (ed.). Latinoyazychnyye istochniki po istorii Drevney Rusi: Sredina XII - sredina XIII v. (Latin-language sources on the history of Ancient Russia: Middle $12^{\text {th }}-$ middle $13^{\text {th }}$ c.). Moscow; Leningrad: Institut istorii AN SSSR, 138 (in Russian).

Veber, M. 2017. Izbrannoye. Protestantskaya etika i dukh kapitalizma (Favorites. Protestant ethics and the spirit of capitalism). Moscow; Saink Petersburg: Tsentr gumanitarnykh initsiativ (in Russian).

Vishlenkova, E.A. 2011. Vizual'noye narodovedeniye imperii, ili "Uvidet' russkogo dano ne kazhdomu" (Visual Ethnic Studies of the Empire, or "Not everyone can see Russian"). Moscow: Novoye literaturnoye obozreniye (in Russian).

Vulf, L. 2003. Izobretaya Vostochnuyu Eevropu: Karta tsivilizatsii v soznanii epokhi Prosveshcheniya (Inventing Eastern Europe: A Map of Civilization in the Mind of the Enlightenment). Moscow: Novoye literaturnoye obozreniye (in Russian).

Gvanini, O. 2007. Khronika evropeys'koi Sarmatii (Chronicle of the European Sarmatian). Kyiv: KievoMogilyans'ka akademíya (in Ukrainian).

Girts, K. 2004. Interpretatsiya kul'tur (Interpretation of Cultures). Moscow: ROSSPEN (in Russian).

Zagadki 1995: Zagadki poslaniya sestre i perepiska Bonifatsiya (Riddles of the message to the sister and the correspondence of Boniface). 1995. In: Ivanov, S.A., Litavrin, G.G., Ronin, V.K. (eds.). Svod drevneyshikh pis'mennykh izvestiy o slavyanakh (The collection of the oldest written information about the Slavs). Vol. 2. Moscow: Vostochnaya literatura, 417 (in Russian).

Kverfurtskiy, B. 2010. In: Dzhakson, T.N., Konovalovoy, I.G., Podosinova, A.V. (eds.). Drevnyaya Rus' $v$ svete zarubezhnykh istochnikov (Ancient Russia in the light of foreign sources). Vol. 4. Moscow: Russkiy fond sodeystviya obrazovaniyu i nauke, $57-58$ (in Russian).

Otto of Freising. 2010. In: Dzhakson, T.N., Konovalovoy, I.G., Podosinova, A.V. (eds.). Drevnyaya Rus'v svete zarubezhnykh istochnikov (Ancient Russia in the light of foreign sources). Vol. 4. Moscow: Russkiy fond sodeystviya obrazovaniyu i nauke, 238-239 (in Russian).

Blaeu, J. 1645. Taurica Chersonesus, Hodie Przecopsca, at Gazara dicitur. Amsterdam: Edited by Willem and Joan Blaeu.

Blaeu, J. 1662. Tractvs Borysthenis Vulgo Dniepr et Niepr dicti, a Chortika Ostro ad Urbem Oczakow. Atlas Maior. Vol. II. Amsterdam: Edited by Willem and Joan Blaeu.

Bruin, A. 1581. Ein reuter aus den land Schithia. Imperii ac Sacerdotii Ornatus. Diuersarum item gētium peculiaris vestitus. Coloniae: [s.n.].

Del'Isle, G. 1706. Carte de Tartarie. Dressee sur les relations de plusieurs voyageurs de differentes nations et sur quelques observations qui ont ete faites dans ce pais la par Guillaume Del'Isle de l'Academie Royale des Sciences. Paris: Chez l'Auteur sur le Quai de l'Horloge a l'Aigle d'Or avec privilege.

Filas, V. 2018. In Skhidnoyevropeys'kyi istorychnyi visnyk (Eastern European Historical Bulletin) 8, 8-17.

Gibbon, E. 1906. The Decline and Fall of the Roman Empire. New York: Fred de Fau and Co.

Homann, I.B. 1720. Tabula geographica qua pars Russiae Magnae, Pontus Euxinus seu Mare Nigrum et Tartaria Minor: cum finitimis Bulgariae, Romaniae et Natoliae Provinciis exhibe[n]tur. Noribergae: Homann (Schul-Atlas von zwantzig General- und Special-Landkarten).

Hondius, G. 1648. Delineatio generalis Camporum Desertorum vulgo Ukraina : cum adjacentibus provinciis / bono publico erecta per Guilhelmum le Vasseur de Beauplan. Danzig: Willem Hondius.

Janssonius, J. 1644. Taurica Chersonesus, Hodie Przecopsca, at Gazara dicitur. Amsterdam: Excudebant Janssonio-Waesbergii et Moses Pitt.

Mercator, G. 1595. Taurica Chersonesus, Nostra aetate. Przecopsca, et Gazara dicitur. Amsterdam: Gerard Mercator.

Rossi, G.G. 1684. Tartaria D Europa ouero Piccola Tartaria divisa da Giacomo Cantelli da Vignola ne Tartari Nogai e del Crim, o di Precop Soggetti al proprio Kam ne Tartari di Budziack, d Oczackow, e di Dobruss, Soggetti al Turco. ne Tartari Circassi, e di Mordua soggetti al Gran Duca di Moscovia e nelle Due Uckraine una abitata da Cosacchi Tanaiti Soggetti al Moscovita, l altra da Cosacchi di Zaporowa, ora liberi, e già dipendenti dalla Polania. Roma: Domenico de Rossi.

Sanson, N. 1665. Tartarie Europeenne ou Petite Tartari ou sont Les Tartares, Du Crim, ou de Perecop; De Nogais, D'Oczacow, et de Budziak. Paris: Mariette P.

Schenk, P. 1680. Taurica Chersonesus, Hodie Przecopsca, at Gazara dicitur. London: Janssonius-Waesberg / Pitt. 


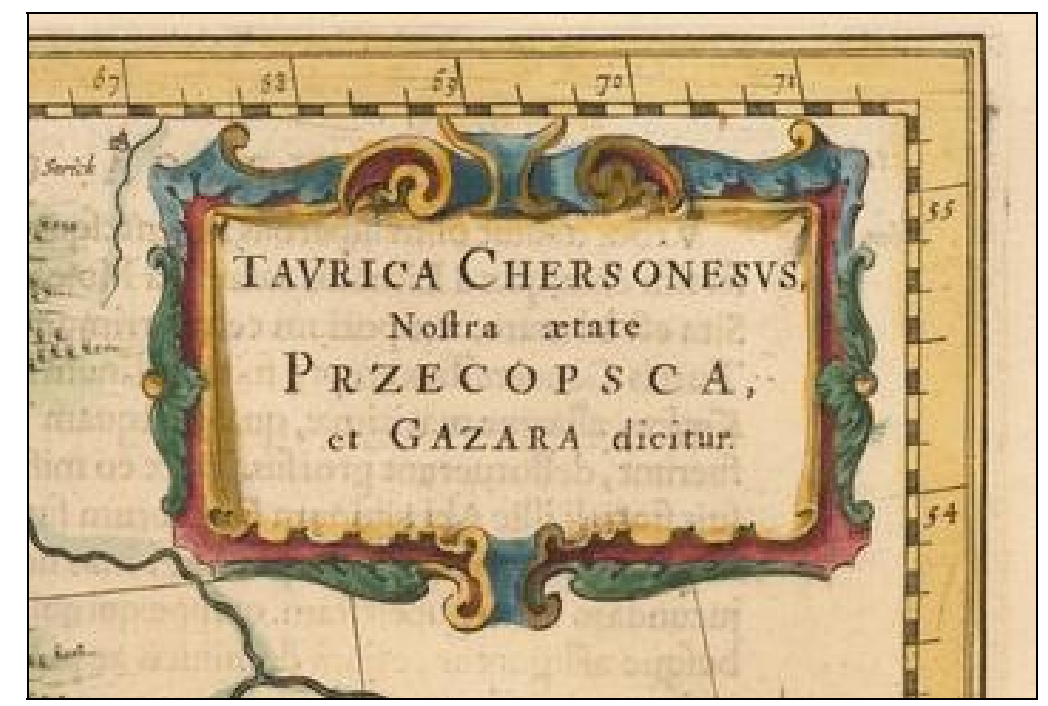

Рис. 1. Картуш к карте Я. Блау «Taurica Chersonesus, Hodie Przecopsca, at Gazara dicitur» 1645 (по Blaeu 1645).

Fig. 1. Cartouche to the map of Jan Blaeu "Taurica Chersonesus, Hodie Przecopsca, at Gazara dicitur" 1645 (after Blaeu 1645).

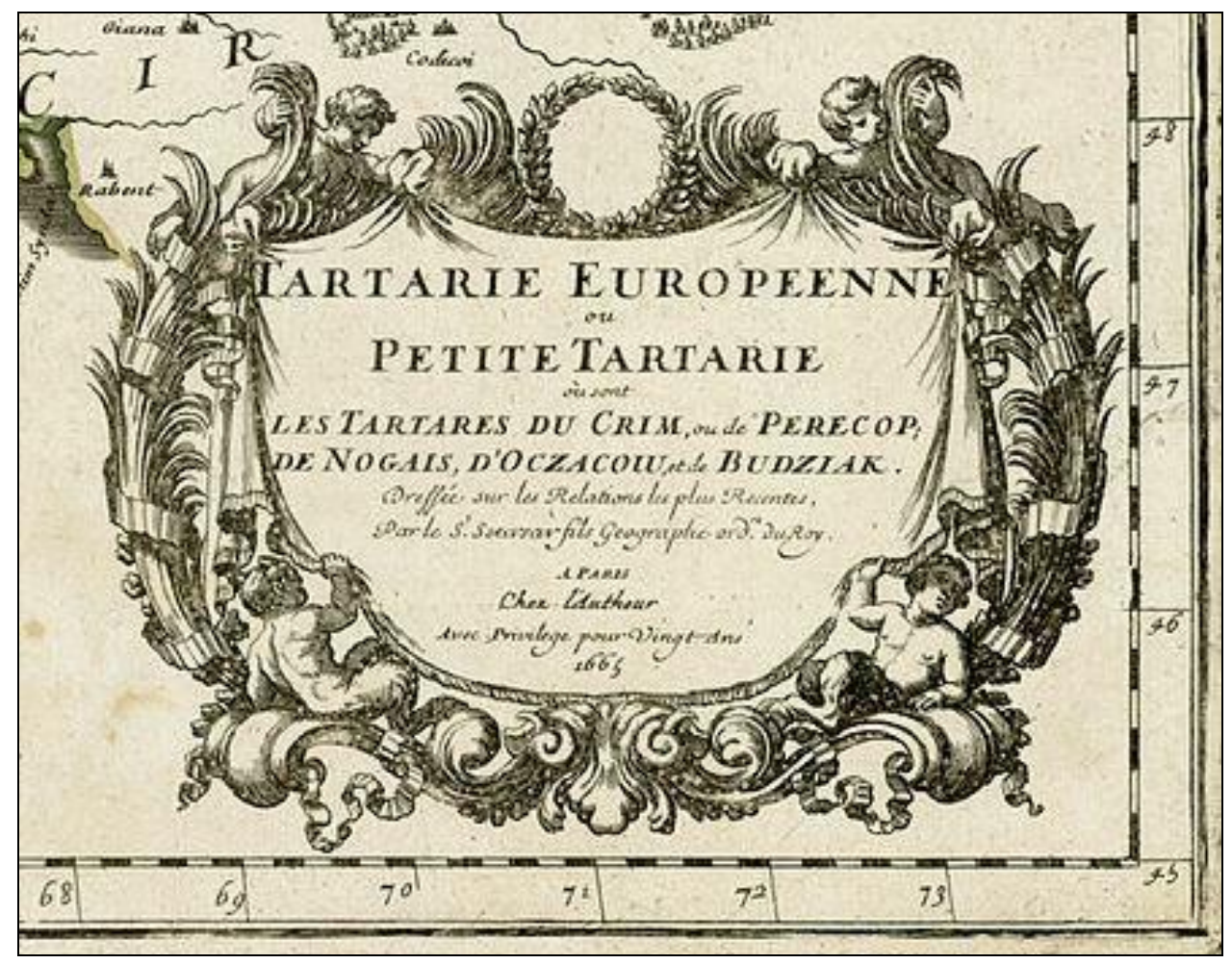

Рис. 2. Картуш к карте Н. Сансона (по Sanson 1665).

Fig. 2. Cartouche to the map of N. Sanson (after Sanson 1665). 


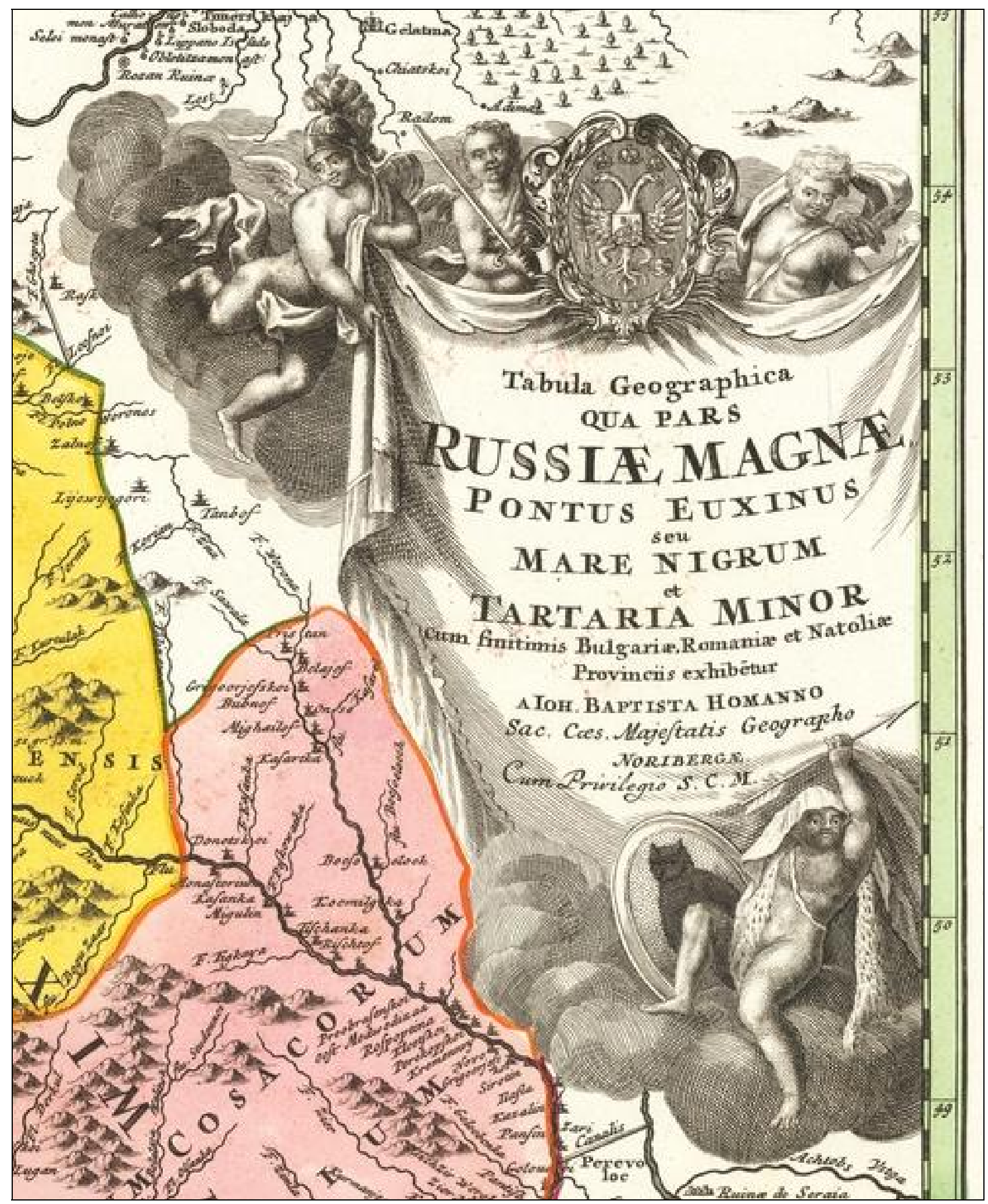

Рис. 3. Картуш к карте И.Б. Хаманна (по Homann 1720).

Fig. 3. Cartouche to the map of Johann Baptist Homann (after Homann 1720). 


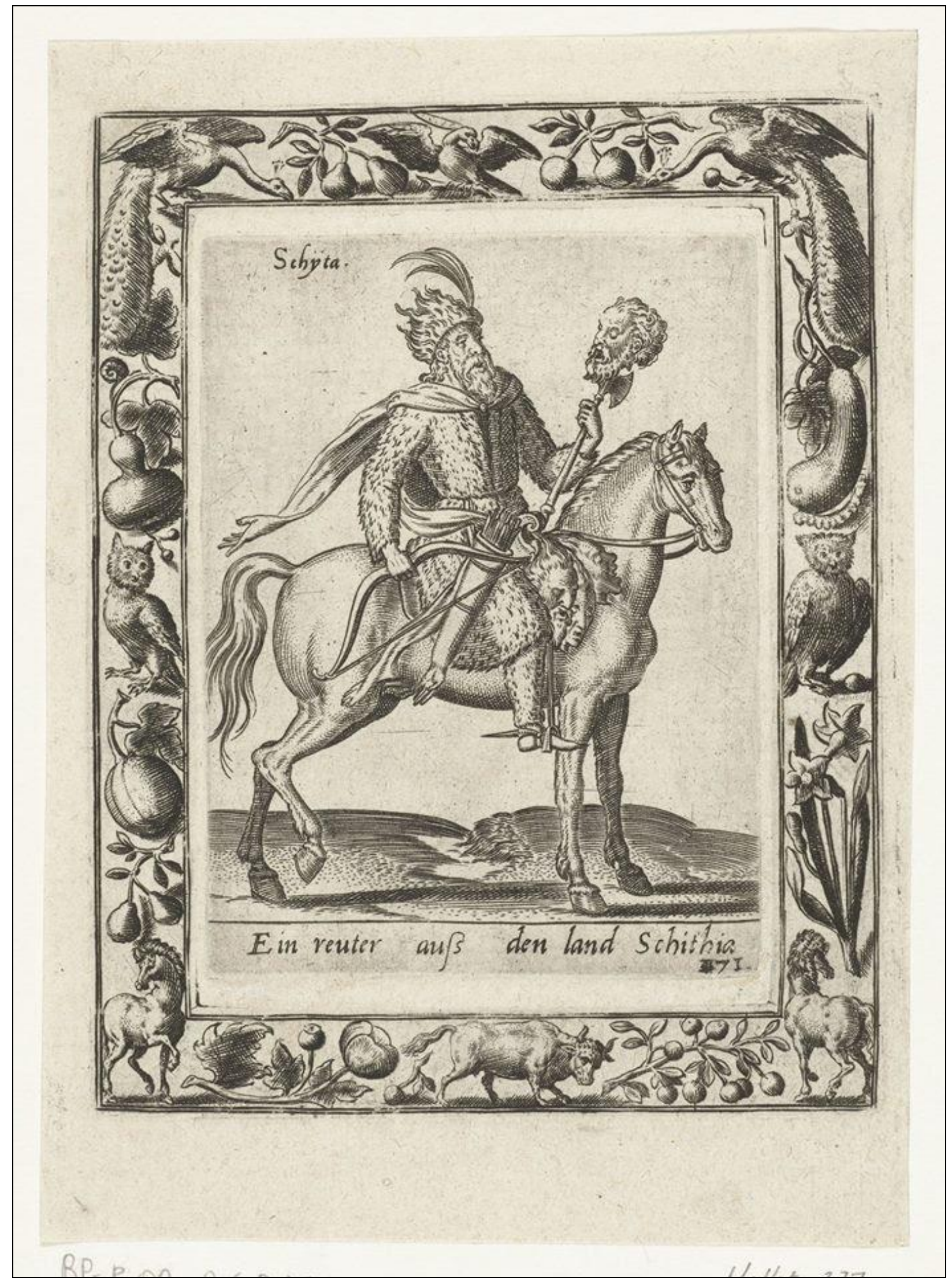

Рис. 4. Скифский всадник работы А. Брейна (по Bruin 1581).

Fig. 4. Scythian horseman by A. Brain (after Bruin 1581). 